\title{
How to Develop Students' Experience on Mathematical Proof in Group Theory Course by Conditioning-Reinforcement-Scaffolding
}

\author{
Mokhammad Ridwan Yudhanegara, Karunia Eka Lestari \\ Universitas Singaperbangsa Karawang \\ Karawang, Indonesia \\ mridwan.yudhanegara@staff.unsika.ac.id, karunia@staff.unsika.ac.id
}

\begin{abstract}
Some mathematicians and mathematics educators attested that students found difficulties in mathematical proving. The difficulties faced by students in conducting mathematical proofs, including: (1) problems in reading and understanding mathematical proofs; (2) presents a mathematical proof; (3) to prove directly, indirectly or by mathematical induction (4) and develop mathematical arguments to prove or disprove a statement. Meanwhile, mathematical proof have an important role in group theory course. As a consequence, mathematical proof is an activity that is too important to ignore. Therefore this study focus on develop students experience of mathematical proof in group theory course by conditioning-reinforcementscaffolding (CRS). The research aprroach is quantitative, and reasearch methods is experiment with quasi experimental design; the matching-only pretest-posttest control group design. The findings show that Ability of mathematical proofs through the implementation of CSR theory better than the ability of mathematical proofs through the implementation of constructivist theory.
\end{abstract}

Keywords - Conditioning, Mathematical Proof, Reinforcement, Scaffolding

\section{INTRODUCTION}

The ability of mathematical proofs is a basic ability that has an important role in the subject of group theory. This is because the course contains a definition of group theory, theorem proving, and the lemma so as the students are able to understand it. Students must have the ability to prove the theorem and lemma they study, as well as to prove some problems related to the application of the definitions, theorems, and lemma [1]

Based on research result [2] in the seventh semester students of the academic year 2014-2015 of Mathematics Education FKIP UNSIKA there are some problems faced by the students in performing mathematical proofs, including problems in: (1) reading and understanding mathematical proofs; (2) presenting a mathematical proof; (3) proving directly, indirectly or by mathematical induction (4) and developing mathematical arguments to prove or disprove a statement.

These problems show that for the students, the ability of mathematical proofs is not easy to achieve. Meanwhile, for the lecturers, teaching mathematical proofs is not an easy matter. In general, it is a matter of applying the theory of constructivism in presenting the material on the group theory course. The learning process through the implementation of constructivist theory in group theory course generally gives more emphasis on process and freedom in exploring knowledge and efforts to construct a mathematical proof independently. Thus, the lecturing activities are dominated by students.

However, the learning process through the implementation of constructivist theory is not so effective when applied to students of Mathematics Education FKIP UNSIKA. The students of Mathematics Education FKIP UNSIKA are mostly workers (part time teachers, administrative personnel, factory workers), meaning that their time has been spent for their working activities than for learning activities, so that the learning time and students' independence in learning are very limited.

Based on these issues, the lecturer plays a dominant role in presenting the material during and outside the course. The lecturer also needs to develop teaching methods that take into account the students' characteristics. This is in line with the fact that the students have limited time for independent learning. That is to say that it is necessary to create habituation (conditioning), reinforcement, and help the students to bridge (scaffold) in constructing the mathematical proofs.

Conditioning is necessary to make the students accustomed to do mathematical proofs. Conditioning process can be carried out through the drill and exercise in the forms of written and oral quizzes through which they are motivated and conscientious in following the conditioning process. The necessary reinforcement can be given with addition and subtraction of scores. Meanwhile, in order to help students to construct mathematical proofs, the lecturer provides scaffolding. Scaffolding is given by techniques of probing, namely: the probing posing, and probing prompting, either in the forms of user authentication, examples of evidence or post materials as well as examples of exercises of proof on the blog page, Facebook, whatsapp (social media) to enable students to learn independently at anytime and anywhere.

Based on the above, it becomes urgent to conduct research on ability of students' mathematical proofs through the implementation of conditioning-reinforcement-scaffolding (CRS) theory in group theory course. This research is expected to contribute to the development of teaching methods, especially for application in group theory course in order to improve students' mathematical proofs. This research aims to determine the students' ability in mathematical proofs through the implementation of CRS theory and students' 
ability in mathematical proofs through the implementation of constructivist theory.

\section{METHOD}

The research uses a quantitative approach, and experiment method with quasi experimental design, namely: pretest-posttest control group design. Experiments carried out by providing treatment through the implementation of CRS theory in group theory course. The treatment is directed to improve the ability of mathematical proofs. Research paradigm is illustrated by [3] in Fig1.$$
\frac{\mathrm{M}}{\bar{M}^{-}} \frac{\mathrm{O}}{\mathbf{O}^{-}} \frac{\mathrm{X}}{\bar{C}^{-}} \overline{\mathbf{O}}^{-}
$$

Fig 1. Research Design

Information:

$\mathrm{M}=$ purposive sampling with subjects matching.

$\mathrm{X}=$ learning through the implementation of CRS theory in group theory course.

$\mathrm{C}=$ learning through the implementation of constructivist theory in group theory course.

$\mathrm{O}=$ observation through the execution of pre-test/ posttest.

The population in this research are all the students of fourth semester of the academic year 2015-2016 Mathematics Education FKIP UNSIKA who follow group theory course. The samples of this research involved are from two groups of students, who are selected using purposive sampling technique with subjects matching. Each group of the samples consists of 32 students. The subject matching is done by pairing individuals based on certain criteria. The criteria are determined by considering the students' prior knowledge on mathematics obtained based on the placement test. It is done in an attempt to obtain an equivalent group. Reference [3] illustrates how to sampling with subject matching as in figure 2.

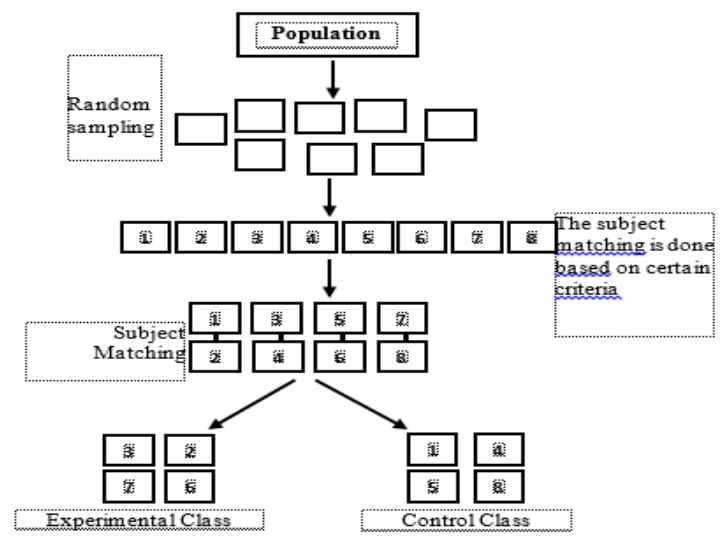

Fig 2. Purposive Sampling Technique with Subjects Matching
Flow data analysis technique is illustrated in Fig 3.

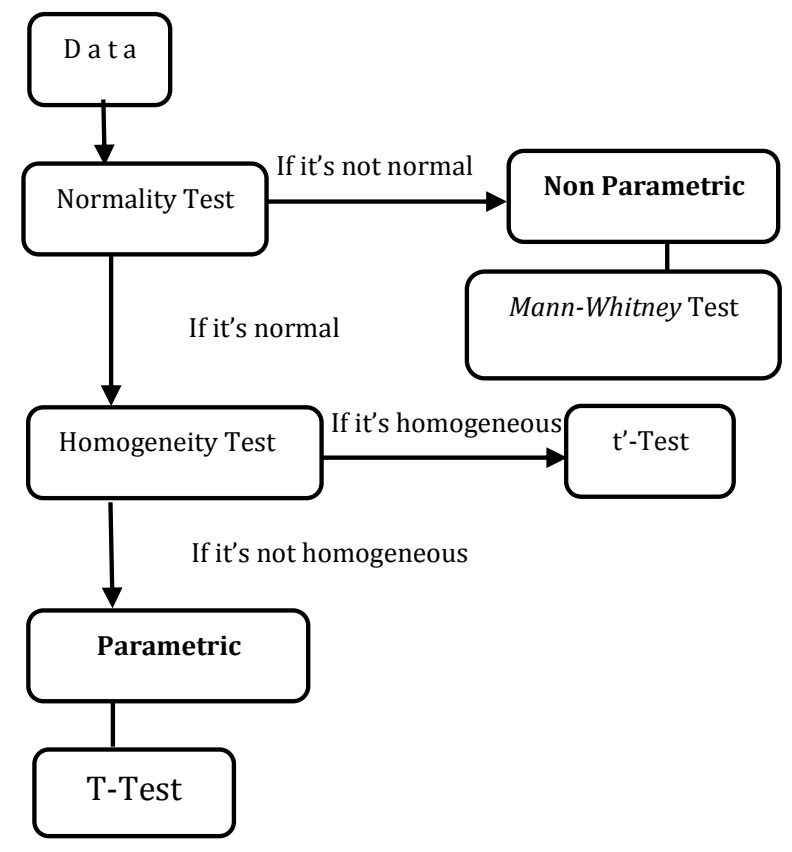

Fig 3. Data Analysis Technique

\section{RESULT AND DISCUSSION}

\section{A. Result of Pretest Data Analysis}

Result of Pretest data analysis is presented in Fig 4.

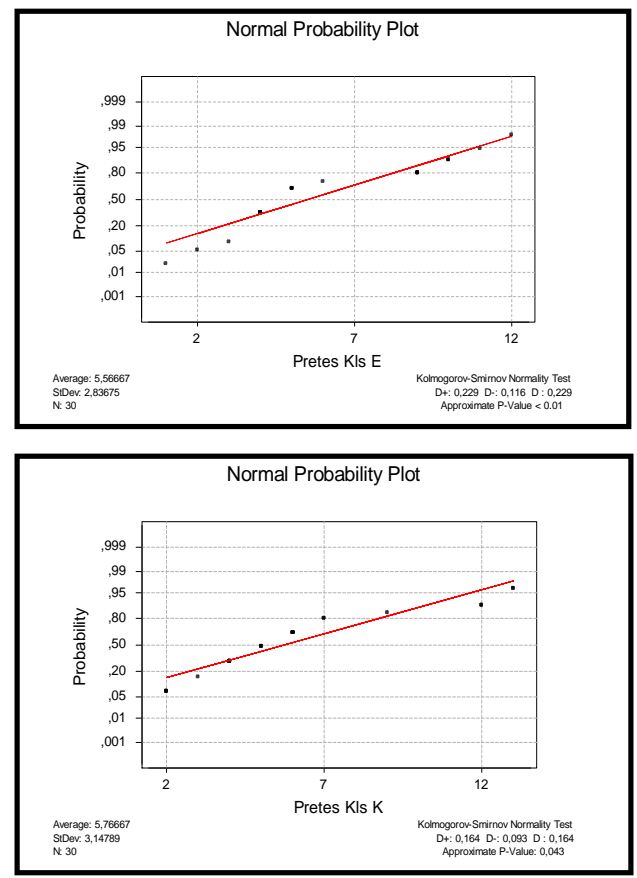

Fig 4. Output of Normality Test for Pre-test Data

Based on Fig 4 it is obtained $\rho$-value for the experimental class and control class, each of which is 0.01 and 0.043 . This 
value is less than 0.05 so that according to the KolmogorovSmirnov test, the sample data for the experimental class and control class are not derived from normal distributed population. Therefore it is not necessary to test the homogeneity, but directly to use the difference tests of two median for non-parametric i.e. Mann-Whitney test.

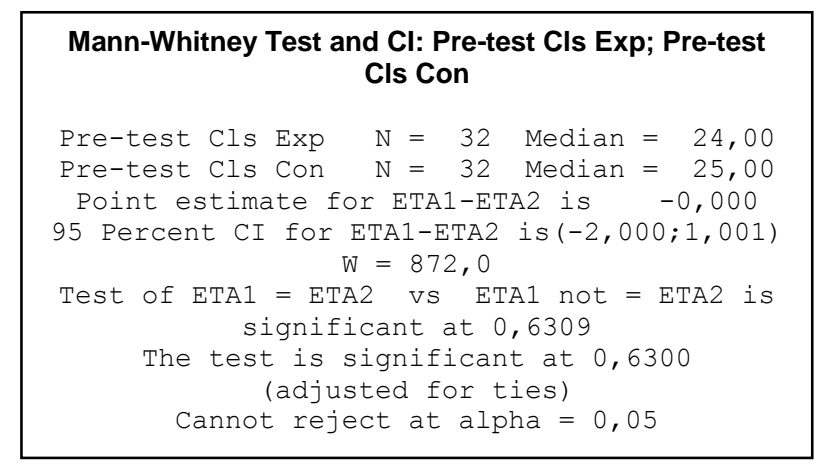

Fig 5. Output of Difference Test of Two Median for Pre-test Data

The value of significance is 0.63 . The value is greater than 0.05 so that based on testing criteria, it shows that the students' prior knowledge of experimental and control classes are the same, or it not significantly different.

\section{B. Result of Posttest Data Analysis}

Result of posttest is presented in Fig 6.

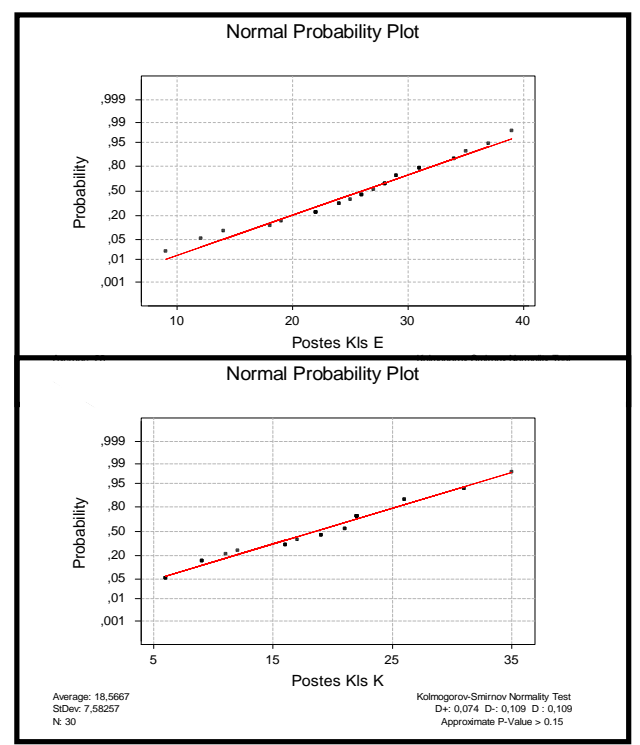

Fig 6. Output of Output of Normality Test for Post-test Data

Based on Fig 4, it is obtained $\rho$-value for the experimental class and control class, each of which is $>0.15$ and $>0.15$. This value is greater than 0.05 so that according to the Kolmogorov-Smirnov test, the sample data for the experimental class and control class are derived from normal distributed population.. Therefore it is necessary to test the homogeneity before difference test of two mean i.e., by using $\mathrm{F}$ test or Lavene Test.

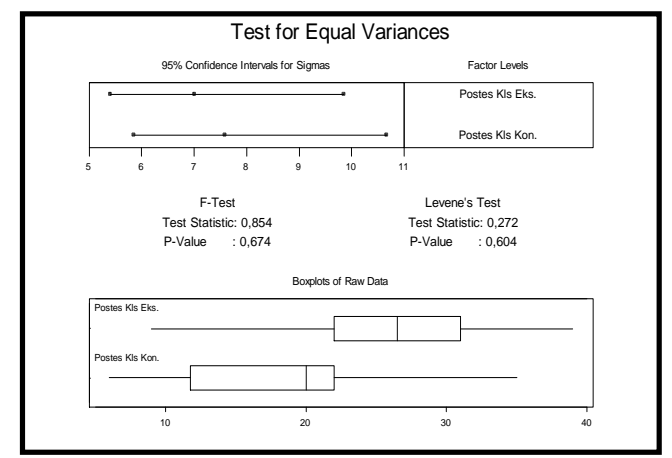

Fig 7. Output of Homogeneity Test for Post-test Data

Based on Fig 7 it shows that the $\rho$-value for the experimental class and control class is 0.674 . This means that the value is greater than 0.05 so that according to the $F$ test it can be said that there is no different variance between the experimental class and control class. Therefore it can be concluded that the data obtained are homogeneous. Furthermore, to compare the two mean value of each class is by using the t test.

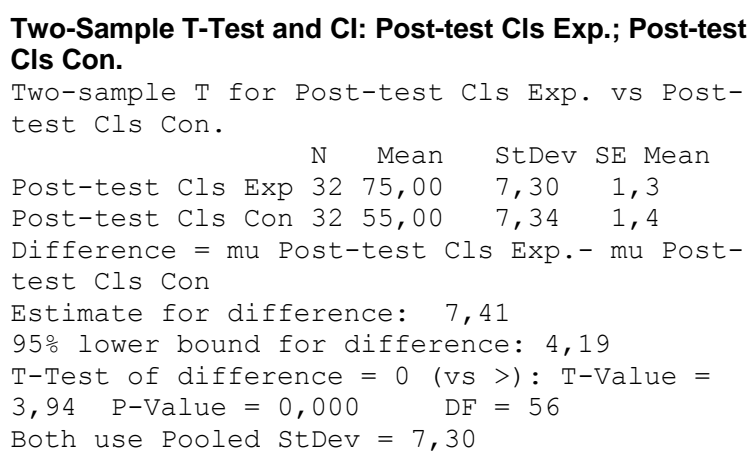

Fig 8. Output of Differences Test of Two Mean for Post-test Data

Fig 8 shows that the value $\rho$-value obtained is 0,000 . This value is less than 0.05 , so that by t-test it can be seen that the average of scores of the experimental class is higher than that of control class. It can be concluded that the students' ability on mathematical proof in experimental class is better than that of control class.

\section{Discussion}

The test result indicates that the students' ability of mathematical proofs through the implementation of CRS theory is better than that through the implementation of the theory of constructivism. This is because in the first phase of implementation of CRS theory, the students are conditioned to get used to perform mathematical proofs through a series of drills and exercise activities. The drills and exercises were held in the form of a written quiz at the beginning of each lecturing process and the oral quiz was conducted during the lecturing process.

In addition, during the second phase students are given an additional reinforcement with a score of 85 for the students to answer questions in an oral quiz, and a reduction in score of 50 students who answered incorrectly and 60 for students who 
cannot answer at all. Thus, this phase requires the student to be trying to optimally perform mathematical proofs. The research result is related to the research from [2] that the CSR theory can help students to improve the ability on mathematics.

In the third phase is the presenting of a number of aids that can bridge or scaffold students to do mathematical proofs. Scaffolding is given by techniques of probing, namely: the probing posing, and probing prompting, either in the forms of user authentication, examples of evidence or post materials as well as examples of exercises of proof on the blog page, Facebook, whatsapp (social media) to enable students to learn independently at anytime and anywhere.

While the implementation of the contructivist theory the lecture does not play a dominant role during and outside courses, on the other hand students are required for understanding the course material without more strategies. Because the relief is only carried out only during course, so there is no control on time outside course. In the implementation of contructivist theory, lecturers do not choose teaching methods according to the characteristics of the students.

\section{CONCLUSION}

The students' ability on mathematical proofs through the implementation of CSR theory is better than that of mathematical proofs through the implementation of constructivist theory due to the students learn through a series of drills and exercise activities.

\section{REFERENCES}

[1] B. R. Findel, "Learning and Understanding in Abstract Algebra. Disertation," Not published, New Hampshire, 2001.

[2] K. E. Lestari, "Analisis kemampuan pembuktian matematis mahasiswa menggunakan pendekatan induktif-dedutif pada mata kuliah analisis real lanjut," Jurnal Mendidik, vol. 1, no. 2, pp. 40-47, 2015.

[3] K. E. Lestari and M. R. Yudhanegara, Penelitian Pendidikan Matematika, Bandung: Refika Aditama, 2015. 